\title{
KINERJA PENELITIAN DOSEN PRODI PENDIDIKAN AGAMA ISLAM \\ FAKULTAS ILMU TARBIYAH DAN KEGURUAN UNIVERSITAS ISLAM NEGERI RADEN FATAH PALEMBANG
}

\author{
Fitri Oviyanti \\ Elly Manizar \\ Dosen Fakultas Ilmu \\ Tarbiyah dan Keguruan \\ UIN Raden Fatah \\ Palembang \\ Puspa Nurulita \\ Mahasiswa S2 PPs UIN \\ Raden Fatah Palembang
}

\begin{abstract}
Abstrak
Salah satu kewajiban dosen sebagai pendidik dan ilmuwan dalam tri dharma perguruan tinggi adalah bidang penelitian, di samping bidang pendidikan pengajaran dan pengabdian. Penelitian (research) pada dasarnya adalah cara ilmiah untuk mendapatkan data dengan tujuan dan kegunaan tertentu. Cara ilmiah berarti kegiatan penelitian itu didasarkan pada ciri-ciri keilmuan, yaitu rasional, empiris, dan sistematis. Penelitian memberikan sumbangan yang sangat berharga, tidak hanya bagi tugas profesional dosen, tetapi juga bagi pengembangan ilmu pengetahuan serta kemajuan masyarakat dan bangsa ini. Untuk itulah, penelitian tentang kinerja penelitian dosen menjadi sangat signifikan.

Penelitian ini menggunakan pendekatan kualitatif dengan informan kunci dosen-dosen tetap PNS Prodi PAI yang dipilih dengan teknik purpossive sampling, mewakili kepangkatan lektor, lektor kepala dan guru besar. Instrumen utama penelitian ini adalah peneliti sendiri (human instrument). Teknik pengumpulan data yang utama adalah wawancara mendalam, observasi, dan studi dokumentasi. Teknik analisis data digunakan menurut Miles dan Huberman, meliputi data reduction, data display, dan conclusion/verification.

Berdasarkan hasil penelitian dapat dijelaskan bahwa secara umum, kinerja penelitian dosen prodi PAI FITK UIN Raden Fatah sudah cukup baik tapi beragam pada masing-masing level kepangkatan. Pada dosen dengan pangkat Lektor, cenderung lebih banyak melakukan kegiatan penelitian daripada menulis buku dan menulis artikel di jurnal atau media massa. Sementara dosen dengan pangkat Lektor Kepala, relatif seimbang kegiatan penelitiannya dengan aktivitas menulis buku dan menulis artikel di jurnal. Selanjutnya, dosen dengan pangkat Guru Besar cenderung lebih banyak melakukan kegiatan penelitian secara mandiri atau berkelompok. Sementara dari sisi kualitas, kinerja penelitian dosen prodi PAI juga cukup baik. Misalnya, laporan-laporan penelitian yang dibuat oleh dosen-dosen prodi PAI tersebut selanjutnya menjadi artikel yang masuk dalam jurnal ilmiah yang ber-ISSN. Atau buku-buku yang ditulis oleh dosen-dosen tersebut telah memiliki ISBN. Selain itu, hasil-hasil penelitian, buku-buku, atau pun tulisan-tulisan dosen prodi PAI di jurnal ilmiah dirasakan pula dampaknya, baik oleh dosen-dosen yang bersangkutan maupun oleh mahasiswa serta teman sejawat.
\end{abstract}

Kata Kunci: Kinerja, Penelitian, Dosen, Prodi PAI FITK UIN RF. 


\section{PENDAHULUAN}

Dosen adalah sarjana yang mempunyai kewajiban menjalankan tugas tri dharma perguruan tinggi atau bidang akademik yaitu pendidikan, penelitian, dan pengabdian kepada masyarakat. Dalam Undang-Undang Republik Indonesia Nomor 14 Tahun 2005 tentang Guru dan Dosen, Bab I Pasal 1 dan Pasal 60 serta Peraturan Menteri Riset, Teknologi dan Pendidikan Tinggi Republik Indonesia Nomor 20 tahun 2017 dijelaskan bahwa dosen merupakan pendidik profesional dan ilmuwan dengan tugas utama mentransformasikan, mengembangkan, dan menyebarluaskan ilmu pengetahuan, teknologi, dan seni melalui pendidikan, penelitian, dan pengabdian kepada masyarakat. Pada pasal 60 butir a dinyatakan bahwa dalam melaksanakan tugas keprofesionalan, dosen berkewajiban melaksanakan pendidikan, penelitian, dan pengabdian kepada masyarakat. Jadi dosen sebagai sarjana, pendidik profesional, dan ilmuwan mempunyai keharusan atau berkewajiban melakukan penelitian, di samping pendidikan dan pengabdian kepada masyarakat.

Penelitian (research) pada dasarnya adalah cara ilmiah untuk mendapatkan data dengan tujuan dan kegunaan tertentu. Cara ilmiah berarti kegiatan penelitian itu didasarkan pada ciri-ciri keilmuan, yaitu rasional, empiris, dan sistematis. Rasional berarti kegiatan penelitian itu dilakukan dengan cara-cara yang masuk akal sehingga terjangkau oleh penalaran manusia. Empiris berarti cara-cara yang dilakukan itu dapat diamati oleh indera manusia, sehingga orang lain dapat mengamati dan mengetahui cara-cara yang digunakan. Sistematis artinya, proses yang digunakan dalam penelitian itu menggunakan langkah-langkah yang tertentu yang bersifat logis (www.pengertianahli.com).

Dalam rubrik BKD (Beban Kerja Dosen) dijelaskan bahwa yang termasuk lingkup penelitian dosen adalah: a) melakukan penelitian (mandiri/ kelompok), b) menulis buku, c) menerjemahkan atau menyadur naskah buku, d) menyunting naskah buku, e) menulis di jurnal ilmiah, f) keikutsertaan dalam forum ilmiah, g) memperoleh hak paten, h) menulis di media massa. Oleh sebab itu, kinerja penelitian dosen yang dimaksud disini bukan berarti hanya kegiatan penelitian, tetapi juga mencakup kemampuan dosen dalam menulis karya ilmiah, baik artikel maupun buku. 
Keterkaitan pelaksanaan penelitian dengan pendidikan dan pengabdian kepada masyarakat terlihat pada manfaat hasil penelitian. Pada Pasal 46 dinyatakan bahwa hasil penelitian bermanfaat untuk:

a. pengayaan Ilmu Pengetahuan dan Teknologi serta pembelajaran;

b. peningkatan mutu Perguruan Tinggi dan kemajuan peradaban bangsa;

c. peningkatan kemandirian, kemajuan, dan daya saing bangsa;

d. pemenuhan kebutuhan strategis pembangunan nasional; dan

e.perubahan Masyarakat Indonesia menjadi Masyarakat berbasis pengetahuan.

Berdasarkan uraian di atas, maka tampak begitu banyak manfaat yang dapat diperoleh dari kegiatan penelitian yang dilakukan oleh dosen bagi tugas profesionalnya serta pengembangan ilmu pengetahuan dan kemajuan bangsa ini. Namun, menurut data statistik, penelitian dosen masih kurang. Hal ini terlihat dari minimnya publikasi karya ilmiah dosen. Dari data DIKTI tahun 2012, publikasi di jurnal internasional dosen tersertifikasi tercatat 2,777 publikasi dosen PTN dan hanya 429 publikasi dosen PTS (Scholae.co/web/read/570/penelitian dosen.antara peluang dan tantangan). Data ini cukup memprihatinkan, tetapi dapat menjadi bahan introspeksi diri bagi perguruan tinggi di Indonesia, terutama bagi dosen.

Munculnya Permenristekdikti no. 20 tahun 2017 tentang pemberian tunjangan bagi dosen yang salah satu isinya menyatakan bahwa dosen dengan pangkat Lektor Kepala, misalnya, harus memiliki tiga karya ilmiah yang dimuat dalam jurnal nasional terakreditasi atau satu karya ilmiah yag dipublikasikan dalam jurnal internasional, sempat menjadi perbincangan hangat dosen-dosen FITK UIN Raden Fatah, terutama dosen PAI. Berbagai tanggapan muncul, baik yang pro maupun yang kontra.

Namun, terlepas dari semua itu, tuntutan kepada dosen untuk meningkatkan kinerja penelitian memang dirasakan semakin menguat. Tidak saja karena penelitian dosen memang merupakan salah satu tugas profesionalnya, tetapi juga karena penelitian akan memberikan banyak manfaat bagi kemajuan hidup masyarakat berbangsa dan bernegara. Meminjam bahasa agama Islam, kinerja penelitian dosen dapat bermakna sebagai "amal jariyah" dosen yang pahalanya akan terus mengalir sampai kapan pun. 
Program Studi Pendidikan Agama Islam (PAI) merupakan salah satu program studi yang ada di lingkungan UIN Raden Fatah Palembang, khususnya Fakultas Ilmu Tarbiyah dan Keguruan. Berdasarkan studi pendahuluan pada bulan Februari 2017, di Prodi PAI menunjukkan data sebagai berikut: jumlah dosen tetap berstatus PNS adalah 26 orang dengan kualifikasi akademik: S2 lima belas orang, dan S3 sebelas orang, dengan perincian jabatan akademik: dua orang guru besar, tiga belas orang Lektor Kepala, dan sebelas orang Lektor (Dokumentasi Prodi PAI).

Menurut sekretaris Prodi PAI, Mardeli, selama kurun waktu dua tahun ini, karya ilmiah dosen PAI cukup banyak, meliputi buku, artikel, dan penelitian. Namun, beliau mengakui bahwa sebaran penelitian dosen PAI tersebut memang belum merata. Artinya, ada beberapa dosen yang memang rajin atau aktif dalam penelitian, tetapi ada juga yang hanya minta dicantumkan namanya saja untuk keperluan Laporan Beban Kinerja Dosen (LBKD). Sepertinya motivasi dosen melakukan penelitian lebih banyak didominasi oleh kewajiban LBKD saja, demikian Mardeli menegaskan (Wawancara dengan Sekprodi PAI). Hal ini juga diungkapkan oleh Nurlaila, bina Skripsi Prodi PAI bahwa karya ilmiah dosen PAI belum banyak terlihat, terutama dalam bentuk buku ajar dan artikel di jurnal ilmiah (Wawancara dengan Bina Skripsi PAI). Sementara itu, salah seorang dosen senior mengatakan bahwa sebenarnya dirinya ingin meneliti, tetapi merasa tidak memiliki kemampuan secara akasdemis untuk meneliti. Kondisi ini membuatnya dilema, karena di satu sisi beliau menyadari kewajibannya sebagai dosen untuk meneliti, tetapi di sisi lain beliau memiliki keterbatasan kemampuan akademis untuk meneliti (Wawancara dengan salah satu Dosen Senior PAI).

Berdasarkan hal di atas, maka tampak bahwa ada permasalahan dalam kinerja penelitian dosen prodi PAI. Dilatarbelakangi oleh hal di atas, maka penelitian ini ingin menelusuri lebih jauh tentang bagaimana kinerja penelitian dosen Prodi PAI Fakultas Ilmu Tarbiyah dan Keguruan UIN Raden Fatah Palembang. Adapun fokus masalah dalam penelitian ini adalah tentang kinerja penelitian dosen Program Studi Pendidikan Agama Islam (PAI) Fakultas Ilmu Tarbiyah dan Keguruan UIN Raden Fatah Palembang.

Penelitian ini bertujuan menganalisis kinerja penelitian dosen Program Studi Pendidikan Agama Islam (PAI) Fakultas Ilmu Tarbiyah dan Keguruan UIN 
Raden Fatah Palembang. Adapun manfaatnya, secara teoritis penelitian ini diharapkan dapat mengembangkan teori tentang kinerja. Secara praktis, penelitian ini diharapkan bermanfaat sebagai bahan masukan (rekomendasi) secara khusus bagi Fakultas Ilmu Tarbiyah dan Keguruan Program Studi Pendidikan Agama Islam (PAI), dan secara umum bagi UIN Raden Fatah Palembang agar dapat menjadi landasan dalam menentukan kebijakan yang terkait dengan penentuan anggaran penelitian dosen.

\section{KERANGKA TEORI}

\section{Pengertian Kinerja Penelitian Dosen}

Dalam Kamus Besar Bahasa Indonesia, kinerja didefinisikan sebagai 1) sesuatu yang dicapai, 2) prestasi yang diperlihatkan, 3) kemampuan kerja (http://kbbi.web.id/kinerja). Kinerja merupakan terjemahan dari kata performance yang berasal dari kata to perform. Beberapa ahli mengatakan sebagai berikut. Dari segi perilaku organisasi, Ivancevich, Konopaske dan Matteson mendefinisikan kinerja (performance) sebagai "hasil-hasil perilaku yang diinginkan" (the desired results of behavior) (John M. Ivancevich, Robert Konopaske, Michael T. Matteson, 2008: 170). Bernardin dan Russell mendefinisikan kinerja sebagai "the record of outcomes produced on a specified job function or activity during a specified time period” (John H. Bernardin, Joyce EA Russel, 1998: 379). Cascio mengatakan "performance refers to an employee's accomplishment of assigned tasks" (kinerja menunjukkan pada penyelesaian atas tugas-tugas yang diberikan kepada pegawai) (Cascio, Wayne F, 1989: 309). Byars dan Rue menerangkan bahwa "the word performance describes the degree of accomplishment of the tasks in an individual's job. It indicates how well the person is fulfilling the requirements of his or her positions, on the basis of result achieved" (kata kinerja mendeskripsikan tingkat penyelesaian tugas-tugas pekerjaan individual, yang menunjukkan seberapa baik seseorang memenuhi persyaratan jabatan atau pekerjaan, berdasarkan hasil yang dicapai) (Byars, Lloyd, LeslieW. Rue, 1979: $345)$.

Pada dasarnya pandangan-pandangan tersebut memiliki pengertian yang sama tentang kinerja, bahwa kinerja adalah tingkat hasil penyelesaian tugas-tugas yang ditetapkan kepada individu atau seseorang untuk memenuhi persyaratan jabatan. Dalam kaitannya dengan tulisan ini dapat dikatakan bahwa kinerja dosen 
dalam bidang penelitian adalah hasil penyelesaian tugas-tugas yang ditetapkan kepada setiap dosen dalam bidang penelitian untuk memenuhi persyaratan jabatannya. Kinerja penelitian dosen dalam bidang penelitian dapat diukur dari hasil pelaksanaan kerja penelitian yang dilakukan selama kurun waktu tertentu misalnya setiap semester yang dibutuhkan untuk memenuhi persyaratan yang berkenaan dengan jabatan dosen.

Milkovich Boudreau menggunakan akronim SMART sebagai tingkat pencapaian tujuan yang menjadi ukuran kinerja yang meliputi Specific results are obtained; Measurable in quantity, quality, and impact; Attainable, challenging yet within view; Relevant to the work unit, organization, career, and so forth; Time-specific, with deadlines to expect a result (Milkovich. George T. John W. Boudreau, 1997: 106). Akronim ini dapat pula menjadi nilai yang dihidupi oleh dosen, dalam menjalankan dharma penelitian. Dengan kata lain berkenaan dengan penelitian dosen, nilai-nilai SMART yang dikemukakan Milkovich dan Boudreau tersebut dapat digunakan untuk mengukur atau dijadikan indikator-indikator kinerja dosen dalam penelitian yang terdiri dari (1) hasil kerja penelitian, (2) jumlah, kualitas, dan dampak penelitian (3) kesuksesan atau kemampuan mencapai target tertentu (4) relevansi penelitian dengan unit kerja (program studi, perguruan tinggi, dan karir); (5) Ketepatan waktu.

Pertama, hasil tertentu yang dicapai dalam penelitian. Hasil tertentu yang dicapai dalam penelitian ini sudah jelas ditetapkan jenisnya. Pedoman Operasional Penilaian Angka Kredit Jabatan Fungsional Dosen ke Lektor Kepala dan Guru Besar telah memberikan deskripsi tentang komponen kegiatan penelitian dan hasilnya serta batas kepatutan jumlah hasil penelitian per semester atau per tahun (lihat tabel 1).

Tabel 1 Komponen Kegiatan Melaksanakan Penelitian dan Batas Kepatutan

\begin{tabular}{|l|l|l|}
\hline NO. & KOMPONEN KEGIATAN & BATAS KEPATUTAN \\
\hline 1 & Menghasilkan karya ilmiah & \\
& Hasil penelitian atau hasil pemikiran & \\
& yang & \\
& dipublikasikan & 1 buku per tahun \\
& 1). Dalam bentuk Buku & 1 buku per tahun \\
& a). Monograf & \\
\hline & b). Buku Referensi & \\
\hline & 2). Dalam majalah ilmiah & \\
\hline
\end{tabular}




\begin{tabular}{|c|c|c|}
\hline & $\begin{array}{l}\text { a). Internasional } \\
\text { b). Nasional terakreditasi } \\
\text { c). Nasional tidak terakreditasi }\end{array}$ & $\begin{array}{l}1 \text { artikel per semester } \\
1 \text { artikel per semester } \\
2 \text { artikel per semester }\end{array}$ \\
\hline & $\begin{array}{l}\text { 3). Melalui seminar } \\
\text { a). Disajikan } \\
\text { (1). Internasional } \\
\text { (2) Nasional }\end{array}$ & $\begin{array}{l}1 \text { makalah per semester } \\
2 \text { makalah per semester }\end{array}$ \\
\hline & $\begin{array}{l}\text { b). Poster } \\
\text { (1). Internasional } \\
\text { (2). Nasional }\end{array}$ & $\begin{array}{l}1 \text { poster per semester } \\
2 \text { poster per semester }\end{array}$ \\
\hline & 4). Dalam koran/majalah Populer/umum & $\begin{array}{l}\text { Maksimal } 10 \% \text { dari } \\
\text { angka kredit minimal } \\
\text { yang diperlu-kan untuk } \\
\text { melaksanakan } \\
\text { Penelitian }\end{array}$ \\
\hline & $\begin{array}{l}\text { Hasil penelitian atau hasil pemikiran yang } \\
\text { tidak dipublikasikan (tersimpan di } \\
\text { perpustakaan perguruan tinggi) }\end{array}$ & $\begin{array}{l}\text { Maksimal } 10 \% \text { dari } \\
\text { angka kredit minimal } \\
\text { yang diperlu-kan untuk } \\
\text { melaksanakan } \\
\text { Penelitian }\end{array}$ \\
\hline 2 & Menerjemahkan/menyadur buku ilmiah & 1 buku per semester \\
\hline 3 & Mengedit/menyunting karya Ilmiah & 1 buku per semester \\
\hline 4 & $\begin{array}{l}\text { Membuat rancangan dan karya teknologi } \\
\text { yang dipatenkan. } \\
\text { Internasional } \\
\text { Nasional }\end{array}$ & $\begin{array}{l}1 \text { karya per tahun } \\
1 \text { karya per semester }\end{array}$ \\
\hline 5 & $\begin{array}{l}\text { Membuat rancangan dan karya teknologi } \\
\text { yang tidak dipatenkan; rancangan dan } \\
\text { karya seni monumental/ seni pertunjukan; } \\
\text { Karya sastra } \\
\text { Tingkat Internasional } \\
\text { Tingkat Nasional } \\
\text { Tingkat Lokal }\end{array}$ & $\begin{array}{l}1 \text { karya per tahun } \\
1 \text { karya per tahun } \\
1 \text { karya per tahun }\end{array}$ \\
\hline
\end{tabular}

Sumber: Ditjendikti Depdiknas, 2009, Pedoman Operasional Penilaian Angka Kredit Jabatan Fungsional Dosen Ke Lektor Kepala dan Guru Besar 
Kedua, jumlah, kualitas, dan dampak penelitian. Berkenaan dengan jumlah hasil penelitian, dari tabel tentang komponen kegiatan penelitian dan jumlah kepatutan karya penelitian di atas, sudah jelas jumlah kegiatan penelitian yang sepatutnya dihasilkan setiap dosen. Berkenaan dengan kualitas hasil penelitian, dapat dikatakan bahwa penelitian yang berkualitas memiliki ciri-ciri pelaksanaan penelitian dilakukan dengan cara-cara kerja yang benar, (2) isi tulisan harus memenuhi syarat-syarat sebuah karya ilmiah yang utuh, yaitu adanya rumusan masalah yang mengandung nilai kebaruan (novelty/ies), metodologi pemecahan masalah, dukungan data atau teori mutakhir yang lengkap dan jelas, serta ada kesimpulan dan daftar pustaka, (3) hasil penelitian atau hasil pemikiran dimuat dalam bentuk buku yang memiliki ISBN, atau majalah ilmiah yang memiliki ISSN (internasional, nasional terakreditasi, nasional tidak terakreditasi), atau prosiding seminar yang memiliki ISBN atau ISSN, atau majalah populer, atau koran (Ditjendikti Depdiknas: 2009).

Berkenaan dengan aspek dampak. Dampak penelitian adalah efek yang ditimbulkan sebagai akibat dari pelaksanaan dan hasil penelitian. Dosen yang aktif melakukan penelitian secara baik dan benar atau berkualitas seperti tersebut di atas, mempunyai hubungan positif dengan kualitas pengajaran, pembelajaran, atau pendidikan karena dengan keaktifan dalam penelitian dosen terlatih berfikir sistematis, mempunyai kemampuan berfikir analitis, deskriptif, dan eksplanatif. Dosen yang demikian aktif melakukan penelitian juga semakin memahami kriteria kebenaran yang obyektif, sehingga dengan kemampuannya ini dosen akan dapat memberikan bimbingan dengan standar kebenaran yang obyektif, dan dapat menjadi standar dalam perilaku (menjadi acuan, teladan). Ketiga, pencapaian target kinerja penelitian. Berdasarkan komponen kegiatan melaksanakan penelitian dan batas kepatutan di atas jelas bahwa setiap dosen pada dasarrnya dapat merencanakan kegiatan atau dharma penelitian yang hendak dilakukan pada setiap semester atau tahun.

Keempat, relevansi hasil penelitian. Setiap dosen mempunyai konsentrasi keahlian atau memiliki kompetensi khusus, sehingga semakin cakap di bidangnya. Relevansi penelitian demikian menyebabkan dosen semakin menguasai bidang studi, bidang ajar, dan dengan demikian juga dapat melaksanakan pengajaran atau pembelajaran dengan semakin baik. Penelitian dosen juga relevan dengan karir, 
karena keaktifan dosen dalam penelitian, dapat mengantarnya pada pemilikan atau capaian jabatan akademik tertentu.

Kelima, ketepatan waktu menyelesaikan penelitian. Kinerja dosen dalam penelitian dapat dilihat pula dari ketepatan waktu menyelesaikan penelitian dan publikasi hasil penelitian dan hasil pemikiran dalam bentuk monograf, buku referensi, majalah ilmiah tingkat internasional, majalah ilmiah nasional baik yang terakreditasi maupun tidak terakreditasi, seminar, publikasi koran, majalah populer, di samping melaksanakan penerjemahan, penyaduran buku ilmiah, mengedit dan menyunting buku ilmiah. Menurut pendekatan laporan beban kerja dosen, dapat dikatakan bahwa setiap dosen harus menyelesaikan penelitian yang direncanakan, sehingga yang bersangkutan dapat melaporkan hasil kerja penelitiannya pada akhir semester.

\section{METODE PENELITIAN}

Penelitian ini menggunakan pendekatan kualitatif dengan informan kunci dosen-dosen tetap PNS Prodi PAI yang dipilih berdasarkan pertimbangan peneliti (purpossive sampling) mewakili kepangkatan lektor, lektor kepala dan guru besar. Instrumen utama penelitian ini adalah peneliti sendiri (human instrument). Teknik pengumpulan data yang utama adalah wawancara mendalam, observasi, dan studi dokumentasi. Teknik analisis data digunakan menurut Miles dan Huberman, meliputi data reduction, data display, dan conclusion/verification.

\section{HASIL PENELITIAN}

\section{Kinerja Penelitian Dosen Prodi PAI FITK UIN Raden Fatah Palembang}

1. Kinerja Penelitian dosen Prodi PAI berpangkat Lektor

\section{a. Hasil kerja Penelitian}

Hasil tertentu yang dicapai dalam penelitian ini sudah jelas ditetapkan jenisnya, baik dalam Pedoman Operasional Penilaian Angka Kredit Jabatan Fungsional Dosen ke Lektor Kepala dan Guru Besar, maupun dalam Pedoman Beban Kinerja Dosen (BKD). (lihat tabel 2.1). Dalam pembahasan ini hanya akan dilihat hasil kerja penelitian dosen dalam empat bentuk, yaitu: melakukan kegiatan penelitian (individu atau kelompok), menulis buku, menulis artikel di jurnal ilmiah, dan menulis artikel di media massa.

Dalam wawancara, informen AD menjelaskan bahwa dalam satu tahun ia melakukan satu kegiatan penelitian. Hasil penelitian itu kemudian dibuat dalam 
bentuk artikel dan dimasukkan ke dalam jurnal Prodi. Ia juga mengaku belum pernah menulis buku (sedang proses), dan belum pernah juga menulis artikel di media massa (Wawancara dengan informen AD, Senin, 14 Agustus 2017). Agak berbeda dengan informen $\mathrm{AD}$, informen $\mathrm{FZ}$ menjelaskan bahwa dalam tiga tahun terakhir ini ia melakukan beberapa penelitian, baik secara mandiri (individu) maupun kelompok (Wawancara dengan FZ, Rabu, 16 Agustus 2017.

Berdasarkan hasil wawancara di atas tampak bahwa di tahun 2016 saja, informen FZ melakukan tiga kegiatan penelitian, baik secara individu maupun kelompok. Ia juga menjelaskan bahwa ia pernah menulis buku dan artikel di jurnal yang ada di lingkungan UIN Raden Fatah Palembang (Wawancara dengan FZ, Rabu, 16 Agustus 2017). Hasil observasi juga menunjukkan bahwa memang benar ditemukan buku karya informen FZ bersama seorang dosen berpangkat Guru Besar. Buku tersebut berjudul Pengembangan Kurikulum (Observasi buku karangan informen FZ, bulan Agustus 2017). Sementara itu, informen AS juga menjelaskan bahwa kalau untuk penelitian, ia pernah diajak penelitian kelompok prodi PGMI tahun yang lalu, tapi beliau lupa judulnya. Ia juga menjelaskan bahwa dalam setahun biasanya ia melakukan satu penelitian, tetapi ia tidak pernah melakukan penelitian secara mandiri (Wawancara dengan AS, Jum'at, 18 Agustus 2017). Namun, kalau hasil penelitian berupa buku, informen AS menjelaskan bahwa ia pernah diajak menulis buku tentang Strategi Pembelajaran oleh teman sejawatnya pada tahun 2015 (Wawancara dengan AS, Jum'at, 18 Agustus 2017).

Jika diamati hasil kerja penelitian dari ketiga informen tersebut, maka tampak informen FZ memiliki hasil kerja penelitian relatif lebih banyak daripada informen $\mathrm{AD}$ dan AS, baik dalam bentuk kegiatan penelitian maupun menulis buku, dan juga menulis artikel di jurnal ilmiah. Informen AD dan AS termasuk dosen yang jarang meneliti (Observasi, kegiatan penelitian informen AD dan AS, bulan Mei sampai Agustus 2017). Sementara itu, untuk pengalaman menulis artikel di jurnal, sebagaimana pengakuan informen $\mathrm{AD}$, biasanya hasil penelitiannya yang dilakukan bersama tim dibuat artikel dan dimasukkan ke dalam jurnal (Wawancara dengan informen AD, Senin, 14 Agustus 2017). Dengan kata lain, pengalaman dosen melakukan penelitian dan pengalaman menulis artikel di jurnal memiliki korelasi yang cukup erat. Khusus untuk 
pengalaman menulis artikel di media massa seperti koran, ketiga informen yang peneliti wawancarai mengaku belum pernah melakukannya.

b. Kualitas dan Dampak kinerja penelitian

Jika diamati beberapa hasil kerja penelitian ketiga informen di atas, maka untuk kegiatan penelitian yang dilakukan oleh informen AD dan FZ tampak sudah memenuhi langkah-langkerja ilmiah yang benar. Hal ini terlihat pada metodologi penelitian yang mereka gunakan (Observasi terhadap laporan kegiatan penelitian informen AD dan FZ, Agustus-September 2017). Sementara hasil penelitian informen AS tidak dapat ditemukan bukti fisiknya, sehingga tidak dapat diamati kualitasnya. Hasil kerja penelitian dalam bentuk buku, yang dapat diamati adalah buku karya informen FZ dan AS. Buku karya FZ sudah memiliki ISBN, sehingga dapat dikatakan cukup berkualitas. Sedangkan buku karya AS belum memiliki ISBN (Observasi terhadap buku karya informen FZ dan AS, Agustus 2017). Dengan demikian dapat disimpulkan bahwa dosen-dosen prodi PAI yang berpangkat Lektor, dari sisi kualitas hasil penelitian belum dapat dikatakan baik.

Selanjutnya, berdasarkan hasil wawancara dengan informen penelitian di atas, untuk dampak akademis, AD mengaku dampak pengalaman penelitian yang ia lakukan sangat besar ketika ia membimbing skripsi mahasiswa, begitu juga dalam kegiatan pembelajaran (Wawancara dengan AM, Senin, 14 Agustus 2017). Informen FZ juga menuturkan hal yang sama (Wawancara dengan informen FZ, Rabu, 16 Agustus 2017). Begitu juga dengan yang dirasakan oleh informen AS (Wawancara dengan informen AS, Jum'at, 18 Agustus 2017). Sementara untuk dampak non akademis, seperti untuk karir, menurut informen FZ, AD, dan AS, mereka menggunakan hasil-hasil penelitiannya untuk naik pangkat dan melengkapi Laporan Beban Kinerja Dosen (LBKD) (Wawancara dengan informen FZ, Rabu, 16 Agustus 2017, Wawancara dengan informen AD, Senin, 14 Agustus 2017, dan Wawancara dengan informen AS, Jum'at, 18 Agustus 2017). Namun, belakangan ini informen AS terhalang persyaratan untuk naik pangkat ke Lektor Kepala yang mensyaratkan harus menempuh pendidikan strata tiga (doktor).

Jika diperhatikan, maka ketiga dosen berpangkat Lektor yang menjadi informen penelitian ini merasakan dampak yang sangat besar bagi sisi akademis mereka. Ketiganya mengakui bahwa dari pengalaman meneliti, mereka 
mendapatkan banyak pengetahuan, wawasan meningkat serta semakin terampil meneliti. Peningkatan wawasan keilmuan ini juga mereka rasakan manfaatnya ketika mengajar dan membimbing mahasiswa dalam penyelesaian skripsi.

Penjelasan di atas relevan dengan hasil wawancara peneliti dengan beberapa informen mahasiswa yang pernah dibimbing atau diajar oleh ketiga informen dosen di atas. Salah seorang mahasiswa bimbingan informen FZ, yaitu ST, menuturkan bahwa informen FZ memberikan masukan yang cukup banyak terkait dengan teori-teori dan metodologi penelitian (Wawancara dengan informen mahasiswa (ST), Selasa, 17 Oktober 2017). Informen mahasiswa lainnya (JR) yang sedang menjalani proses bimbingan menjelaskan bahwa informen FZ membimbingnya secara bertahap, mulai dari perbaikan judul, teoriteori serta metodologi penelitian (Wawancara dengan informen mahasiswa (JR), Selasa, 17 Oktober 2017). Berdasarkan hasil wawancara dengan dua informen mahasiswa tersebut, maka tampak bahwa mereka dibimbing dengan prosedur keilmuan yang benar. Hal ini menunjukkan bahwa pengalaman informen FZ dalam kegiatan penelitian memang memiliki dampak akademis yang besar sebagaimana penjelasannya.

Seorang informen mahasiswa dengan inisial WY yang pernah mengambil mata kuliah Ilmu Tauhid dengan informen dosen AD menjelaskan bahwa ketika mengajar, informen $\mathrm{AD}$ selalu mengaitkan pokok bahasan dengan pengalamannya, sehingga mahasiswa cepat mengerti (Wawancara dengan informen WY, Kamis, 26 Oktober 2017). Penjelasan informen WY ini menggambarkan bahwa ia merasakan pengalaman belajar yang baik dan menyenangkan dengan informen AD. Sebab, informen AD selalu mengaitkan pembahasan dalam perkuliahan dengan pengalamannya, sehingga mahasiswa mendapatkan ilustrasi atau contoh-contoh yang mudah mereka pahami.

Mencermati beberapa penjelasan dari informen-informen mahasiswa di atas, maka dapat dimaknai bahwa pada dasarnya kinerja penelitian dosen prodi PAI cukup dirasakan dampak akademisnya oleh mahasiswa. Sementara itu, untuk dampak non akademis, umumnya informen dosen dalam penelitian ini mengaku bahwa sebelumnya hasil-hasil penelitian memang dapat dimanfaatkan untuk naik pangkat. Namun, sejak ada peraturan pemerintah yang mengharuskan kenaikan pangkat dari Lektor ke Lektor Kepala harus menempuh pendidikan doktor, maka 
hasil-hasil penelitian tersebut cenderung dimanfaatkan untuk keperluan memenuhi Beban Kinerja Dosen saja.

c. Kesuksesan/kemampuan mencapai target tertentu dalam penelitian

Informen AD menjelaskan bahwa setiap awal tahun ia selalu merencanakan penelitian dan menulis buku. Jika tidak tercapai target itu, maka rencana awal wilayah penelitiannya ia pindahkan ke tempat yang lebih dekat (Wawancara dengan AD, Senin, 14 Agustus 2017). Agak berbeda dengan pendapat AD, informen FZ menjelaskan bahwa ia tidak selalu merencanakan penelitian setiap tahun, tergantung mood-nya. Kalau sudah ada rencana penelitian, maka ia mengaku membuat target agar dapat bekerja secara prioritas, serta melibatkan mahasiswa untuk membantu mengumpulkan data (Wawancara dengan FZ, Rabu, 16 Agustus 2017). Selanjutnya, informen AS menjelaskan juga bahwa hampir di setiap awal tahun ia merencanakan kinerja penelitian. Untuk merealisasikan rencana tersebut, ia berusaha mencari tema-tema yang menarik dan aktual untuk diteliti (Wawancara dengan AS, Jum'at, 18 Agustus 2017). Informen AS juga menambahkan bahwa agar penelitian yang sedang dilakukannya selesai tepat waktu, maka akan mencari literatur-literatur yang menunjang serta melibatkan mahasiswa dalam penulisan (Wawancara dengan AS, Jum'at, 18 Agustus 2017).

Berdasarkan hasil observasi, informen AD, FZ, dan AS termasuk dosendosen yang selalu ikut berpartisipasi aktif memasukkan proposal penelitian setiap tahunnya yang dibiayai oleh LP2M UIN Raden Fatah Palembang (Observasi kegiatan penelitian informen AD, FZ, dan AS, bulan Mei 2017). Hal ini dapat dimaknai bahwa pada dasarnya dosen-dosen prodi PAI yang berpangkat Lektor, telah merencanakan kegiatan penelitian setiap tahunnya. Dosen-dosen tersebut juga telah merencanakan usaha-usaha untuk mencapai target rencana penelitian, sesuai style masing-masing. Ada yang meningkatkan manajemen waktu, ada juga yang melibatkan partisipasi aktif mahasiswa.

d. Relevansi penelitian dengan unit kerja (program studi, perguruan tinggi, dan karir); dan ketepatan waktu.

Menurut informen $\mathrm{AD}$, penelitian yang ia lakukan selama ini selalu relevan dengan program studi home base-nya, yaitu Pendidikan Agama Islam PAI (Wawancara dengan AD, Senin, 14 Agustus 2017). Informen FZ juga menjelaskan bahwa kinerja penelitiannya, baik dalam bentuk penelitian maupun 
menulis buku, selalu sesuai dengan program studi dan keilmuannya (Wawancara dengan FZ, Rabu, 16 Agustus 2017). Informen AS pun menjelaskan bahwa selama ini ia melakukan penelitian yang sesuai dengan program studi dan keilmuannya. Ia juga menjelaskan bahwa dulu home base-nya prodi PGMI, tapi sekarang sudah pindah ke prodi PAI sesuai dengan latar belakang keilmuannya (Wawancara dengan AS, Jum'at, 18 Agustus 2017).

Berdasarkan hasil observasi terhadap karya-karya penelitian ketiga informen di atas, maka tampak bahwa selama ini informen FZ, misalnya, sudah melakukan penelitian yang relevan dengan program studi dan kelimuannya. Misalnya, penelitian FZ tahun lalu yang dilakukannya bersama tim dosen prodi PAI berjudul Respon dan Ekspektasi Guru Pamong terhadap Kompetensi Keguruan Mahasiswa PPLK II Prodi PAI. Penelitian ini berupaya menggali data tentang respon dan ekspektasi guru-guru pamong yang berada di sekolah-sekolah mitra FITK, yang selama ini menjadi tempat Praktik Pengalaman Lapangan Kependidikan II (PPLK II) mahasiswa FITK (Observasi dan studi dokumentasi terhadap hasil penelitian informen FZ, Agustus 2017). Demikian juga dengan karya FZ dalam bentuk buku ajar berjudul Kurikulum dan Pembelajaran. Buku ini memiliki ISBN dan banyak dirujuk oleh mahasiswa FITK dalam membuat kaya ilmiah (Observasi karya tulis mahasiswa yang merujuk pada buku karya informen FZ, Juli-Agustus 2017). Hal ini menunjukkan bahwa buku yang ditulis oleh FZ bersama teman sejawatnya tersebut memiliki relevansi dengan perguruan tinggi.

Sementara itu, informen AD juga melakukan penelitian yang terkait dengan metodologi pembelajaran al-Qur'an. Hal ini tercermin dari judul penelitiannya, yaitu Implementasi metode JIBRIL dalam menghafal al-Qur'an di SDIT Ar-Ridho Palembang.Walaupun tidak berhubungan langsung dengan materi pembelajaran PAI di sekolah, tetapi metode pembelajaran al-Qur'an merupakan salah satu komponen penting yang ikut menentukan keberhasilan pembelajaran PAI.

\section{Kinerja Penelitian dosen Prodi PAI berpangkat Lektor Kepala}

a. Hasil kerja Penelitian

Informen MS menjelaskan bahwa ia pernah melakukan penelitian kelompok, tetapi namanya tidak tercantum dalam Surat keputusan (SK) (Wawancara dengan MS, Senin, 14 Agustus 2017). Untuk penelitian mandiri, MS mengaku belum pernah melakukannya. Informen AM menjelaskan bahwa 
kegiatan penelitiannya dalam beberapa tahun terakhir masih terkait dengan home base-nya yang lama, yaitu Fakultas Ushuluddin dan Pemikiran Islam. AM menjelaskan bahwa tahun 2016 ia melakukan penelitian mandiri tentang Kesadaran Beragama dan Makna Ibadah bagi Lansia Muslim dengan pendekatan kualitatif (Wawancara dengan AM, Senin, 14 Agustus 2017). Sementara itu, informen ZH menjelaskan bahwa di tahun 2016, ia pernah melakukan penelitian tentang Melayu yang didanai oleh LP2M UIN Raden Fatah. Di tahun ini (2017), ia juga melakukan penelitian yang berbasis pengembangan ilmu (Wawancara dengan ZH, Selasa, 15 Agustus 2017).

Memperhatikan hal ini, maka secara umum dapat disimpulkan bahwa informen AM dan $\mathrm{ZH}$ memiliki pengalaman melakukan penelitian, khususnya secara mandiri. Sementara itu, informen MS pada dasarnya belum memiliki pengalaman dalam kegiatan penelitian. Terkait dengan pengalaman menulis buku, informen MS menjelaskan bahwa dalam satu tahun biasanya ia menulis satu buku (Wawancara dengan MS, Senin, 14 Agustus 2017). Berikut ini penjelasannya:

"Buku yang aku tulis ado, cak buku Masail al-fiqhiyah, buku Ushul Fiqh. Aku lebih seneng nulis buku karno aku dak galak ribet berurusan dengan wong banyak. Kalu nulis buku kan biso dewe'an. (Wawancara dengan MS, Senin, 14 Agustus 2017)”

Berbeda dengan penjelasan MS di atas, informen AM justeru mengaku belum pernah menulis buku (Wawancara dengan AM, Senin, 14 Agustus 2017). Namun, setelah diobservasi ternyata informen AM pernah menulis buku Metodologi Penelitian, (Observasi hasil penelitian AM dalam bentuk buku ajar Metodologi Studi Islam, Agustus 2017) tetapi menurutnya sudah lama sekali. Buku itu ia tulis ketika masih berstatus sebagai dosen Fakultas Ushuluddin. Sementara itu, informen ZH menjelaskan bahwa ia pernah menulis buku Psikologi Islam, Kamus Baso Pelembang, dan Aplikasi Metode PAIKEM bersama tim dosen prodi PAI (Wawancara dengan ZH, Selasa, 15 Agustus 2017).

Berdasarkan hasil wawancara, observasi dan studi dokumentasi tersebut, maka dapat disimpulkan bahwa ketiga informen penelitian tersebut memiliki hasil kerja penelitian dalam bentuk buku. Buku-buku yang ditulis berkaitan langsung dengan basic keilmuan yang biasanya merupakan mata kuliah yang menjadi kompetensi dosen tersebut. Jika dibandingkan dengan hasil kerja dalam bentuk kegiatan penelitian, informen MS mengaku lebih tertarik atau lebih suka menulis 
buku. Sebab, seperti pengakuannya, meneliti itu ribet karena berurusan dengan banyak orang. Sepertinya, informen MS termasuk orang yang memiliki kepribadian introvert. Ia tidak suka berinteraksi dengan banyak orang.

Sementara itu, informen AM termasuk dosen yang cukup memiliki hasil kerja penelitian dalam bentuk laporan penelitian, dan buku. Setidaknya dalam satu tahun, ia menghasilkan satu kegiatan penelitian yang lalu ia jadikan buku. Kemudian, informen $\mathrm{ZH}$ termasuk dosen yang memiliki hasil kerja penelitian yang seimbang antara menulis buku dengan melakukan penelitian. Hal ini terbukti pada hasil karyanya, ada yang berbentuk buku ajar atau pun laporan penelitian yang kemudian dibukukan. Dalam satu tahun, ia dapat dipastikan melakukan satu kegiatan penelitian.

Dengan demikian, secara umum dapat disimpulkan bahwa setiap tahunnya, dosen prodi PAI yang berpangkat Lektor Kepala rata-rata menghasilkan satu karya hasil penelitian. Namun, hasil penelitian itu beragam, ada yang berbentuk laporan penelitian, ada yang berupa buku, ada pula artikel dalam jurnal ilmiah. Belum ada kinerja penelitian dosen PAI dalam bentuk tulisan (artikel) di media massa. Kecenderungan yang tampak untuk hasil kerja penelitian dosen prodi PAI yang berpangkat Lektor Kepala adalah melakukan kegiatan penelitian secara mandiri.

b. Kualitas dan Dampak kinerja penelitian

Berdasarkan observasi, kegiatan-kegiatan penelitian yang dilakukan oleh informen $\mathrm{ZH}$ dan $\mathrm{AM}$ sudah memenuhi kriteria atau prosedur kerja penelitian yang benar sesuai pendekatan penelitian yang dipilih oleh masing-masing informen (Observasi laporan penelitian informen ZH dan AM, Agustus 2017). Sementara kegiatan penelitian yang dilakukan oleh informen MS tidak ditemukan, sehingga tidak dapat diamati. Namun, informen MS mempunyai buku yang ditulisnya sendiri. Judulnya Masail al-Fiqhiyyah, tetapi buku ini tidak memiliki ISBN (Observasi buku karya informen MS, Agustus 2017). Informen AM juga pernah menulis buku dari hasil penelitiannya, tetapi juga tidak ada ISBN (Observasi buku karya informen AM, Agustus 2017). Berbeda dengan informen ZH yang memiliki karya berupa buku Psikologi Agama yang telah ber-ISBN (Observasi pada buku karya informen ZH, Agustus 2017). 
Selanjutnya, untuk dampak akademis dari kinerja penelitian, informen MS menjelaskan bahwa buku yang ia tulis memiliki dampak akademis yang sangat besar, terutama ketika mengajar dan membimbing mahasiswa (Wawancara dengan MS, Senin, 14 Agustus 2017). hal senada juga dijelaskan oleh AM juga. Menurutnya, pengalaman penelitian dapat ia tularkan kepada mahasiswa bimbingannya, misalnya teliti dan serius menggali data (Wawancara dengan AM, Senin, 14 Agustus 2017). Sesuai dengan penjelasan ini, informen $\mathrm{ZH}$ juga menjelaskan bahwa pengalaman meneliti sangat membantunya dalam membimbing mahasiswa (Wawancara dengan ZH, Selasa, 15 Agustus 2017).

Mendukung penjelasan di atas, Informen MY, seorang mahasiswa semester sembilan, prodi PAI yang sedang dibimbing skripsinya oleh informen $\mathrm{ZH}$ menjelaskan bahwa $\mathrm{ZH}$ membimbingnya per bab, mulai dari judul sampai cara menganalisis (Wawancara dengan informen MY, Senin, 23 Oktober 2017). Informen MY juga pernah mengambil mata kuliah dengan informen $\mathrm{ZH}$. Pengalamannya ketika mengambil mata kuliah Psikologi Agama dengan informen $\mathrm{ZH}$, agak sulit memahami bahasan dalam buku tersebut.

Agak berbeda dengan pengalaman informen MY di atas, informen LR yang juga mahasiswa bimbingan informen $\mathrm{ZH}$ menjelaskan bahwa $\mathrm{ZH}$ membimbingnya membuat kisi-kisi untuk latar belakang penelitian, dan saran tentang instrumen pengumpul data yang tepat. Ia juga pernah mengikuti mata kuliah Psikologi Agama yang diampu oleh informen ZH. Menurut LR, ada bahasan yang agak sulit dipahami dari buku tersebut, tetapi setelah dijelaskan $\mathrm{ZH}$, ia dapat memahaminya (Wawancara dengan informen LR, Senin, 23 Oktober 2017).

Hampir sama dengan penjelasan di atas, informen NM menjelaskan bahwa walaupun sempat dirombak dari awal, tapi masukan dari informen $\mathrm{ZH}$ tentang metode penelitian dan teori-teori yang relevan dengan bahasannya sangat penting bagi penyelesaian skripsinya (Wawancara dengan informen NM, Senin, 23 Oktober 2017). Berdasarkan keterangan dari beberapa informen mahasiswa tadi, maka tampak bahwa ketiganya menjalani proses bimbingan skripsi yang berbedabeda tingkat kesulitannya. Akan tetapi, secara umum dapat disimpulkan bahwa mereka merasa mendapatkan bimbingan yang baik dari informen ZH. Dari penjelasan ketiganya tampak bahwa informen $\mathrm{ZH}$ memberikan bimbingan yang 
cukup sistematis dan terarah. Misalnya, dalam membuat latar belakang diberikan arahan berupa kisi-kisi, sehingga mahasiswa memiliki acuan yang benar dan jelas.

Selain itu, buku yang merupakan salah satu hasil kerja penelitian informen $\mathrm{ZH}$, digunakan oleh mahasiswa dalam proses perkuliahan. Buku tersebut menjadi salah satu referensi penting bagi mahasiswa dalam membuat makalah yang selanjutnya didiskusikan di dalam kelas. Walaupun ada informen mahasiswa tadi yang menyatakan sedikit kesulitan dalam memahami pembahasan dalam buku tersebut, tetapi kesulitan itu hanya sebatas penerapan metode perkuliahan. Pejelasan informen $\mathrm{ZH}$ sebagai dosen pengampu mata kuliah tersebut di akhir sesi diskusi, menurut mereka sangat baik dan dapat mengatasi semua kesulitan pemahaman mahasiswa di awal pembahasan.

Selanjutnya, informen HD, seorang mahasiswa prodi PAI, angkatan 2012 yang sedang dalam proses bimbingan skripsi dengan informen AM menjelaskan bahwa ia dibimbing oleh AM sekitar enam bulan. Masukan- masukan AM cukup banyak, misalnya penggunaan teori-teori yang relevan, pendekatan penelitian yang sesuai, penentuan sample penelitian, teknik analisis data, serta teknik penulisan (Wawancara dengan informen HD, Rabu, 1 November 2017). Hal ini dapat dimaknai bahwa informen AM memberikan bimbingan yang cukup baik pada mahasiswanya. Informen AM memberikan masukan dan saran-saran yang tidak hanya terkait dengan teknis penulisan skripsi, tetapi juga masukan tentang teori-teori yang harus dirujuk oleh mahasiswa, serta teknik analisis data yang sesuai dengan jenis penelitian.

Sementara untuk dampak non akademis, seperti untuk karir, informen MS mengaku tidak pernah menggunakan hasil penelitiannya untuk naik pangkat. Alasannya karena ia tidak mau ribet (Wawancara dengan MS, Senin, 14 Agustus 2017). Sama seperti informen MS, informen AM juga menjelaskan bahwa hasil penelitiannya dipakai untuk laporan BKD saja (Wawancara dengan AM, Senin, 14 Agustus 2017). Namun, bagi informen ZH, dampak kinerja penelitiannya bagi karir adalah untuk kenaikan pangkat juga, di samping untuk laporan Beban Kinerja Dosen (BKD) (Wawancara dengan ZH, Selasa, 15 Agustus 2017). Observasi peneliti juga menunjukkan bahwa ketiga informen tersebut lebih cenderung menggunakan hasil penelitiannya untuk memenuhi kewajiban BKD (Observasi terhadap dampak non akademis kinerja penelitian dosen ; informen 
MS, AM, dan ZH, bulan Agustus 2017). Sementara kalau untuk naik pangkat, informen MS dan AM tidak merasakannya, karena proses mengurus pangkat ribet, dan sekarang online.

c. Kesuksesan/kemampuan mencapai target tertentu dalam penelitian

Sehubungan dengan kemampuan dosen untuk mencapai target tertentu dalam penelitian, informen MS menjelaskan bahwa ia berencana merevisi buku Ushul Fiqh karyanya. Agar terealisasi, ia selalu meluangkan waktu untuk menulis selama dua jam setiap hari, selesai sholat subuh (Wawancara dengan MS, Senin, 14 Agustus 2017). Ketika ditanya bagaimana antisipasinya jika rencana merevisi buku tidak tercapai, MS dengan penuh semangat menjawab: "Pokoknya harus selesai, itu target aku." (Wawancara dengan MS, Senin, 14 Agustus 2017 Wawancara dengan MS, Senin, 14 Agustus 2017) Informen AM juga menjelaskan bahwa dalam tahun ini ia berencana menulis satu buku. Supaya cepat selesai, maka ia akan menulis secara berangsur-angsur (Wawancara dengan AM, Senin, 14 Agustus 2017). Sama seperti informen MS, ketika ditanya apa yang akan dilakukannya jika target menulis buku tersebut tidak tercapai, informen AM dengan tegas menjawab: "Aku nakfokus nulis" (Wawancara dengan MS, Senin, 14 Agustus 2017). Mendukung penjelasan kedua informen tersebut, informen ZH juga menjelaskan bahwa ia merencanakan untuk meneliti, menulis buku, dan menulis artikel di jurnal (Wawancara dengan ZH, Selasa, 15 Agustus 2017). Untuk merealisasikan rencana tersebut, informen $\mathrm{ZH}$ menjelaskan bahwa ia akan menyiapkan proposal penelitian. $\mathrm{ZH}$ mengutarakan keinginannya untuk mendapatkan peluang penelitian dari luar UIN Raden Fatah.

Ketika ditanya bagaimana antisipasinya jika rencana penelitian tersebut tidak tercapai, informen $\mathrm{ZH}$ menjawab bahwa ia akan melanjutkan penelitian tersebut sebagai penelitian mandiri, dan diterbitkan dalam bentuk buku, serta artikel. Dengan demikian, maka dapat dianalisis bahwa semua informen penelitian ini merencanakan penelitian setiap tahunnya, baik dalam bentuk rencana kegiatan penelitian, maupun rencana menulis buku atau merevisi buku. Ketiganya juga telah merencanakan strategi untuk merealisasikan rencana penelitian masingmasing serta usaha-usaha antisipasinya.

d. Relevansi penelitian dengan unit kerja (program studi, perguruan tinggi, dan karir); dan ketepatan waktu. 
Menurut informen MS, buku-buku yang ia tulis selama ini sudah sesuai dengan disiplin ilmu yang ditekuninya, yaitu hukum Islam (Wawancara dengan MS, Senin, 14 Agustus 20170. Buku-buku yang ditulis MS antara lain adalah Masail al-Fiqh, Ushul al-Fiqh (Observasi terhadap buku-buku karya informen MS, bulan Agustus 2017). Berbeda dengan yang dilakukan oleh informen MS, informen AM mengaku selama ini ia menulis buku yang sesuai dengan mata kuliah yang diajarkannya, yaitu Metodologi penelitian, dan juga sesuai dengan unit kerjanya yang dulu (Fakultas Ushuluddin) (Wawancara dengan AM, Senin, 14 Agustus 2017). Sementara itu, informen ZH menjelaskan bahwa kinerja penelitian yang dilakukannya selama ini selalu relevan, baik dengan program studi maupun keilmuannya, yaitu Psikologi Agama (Wawancara dengan ZH, Selasa, 15 Agustus 2017).

Sesuai dengan hasil wawancara di atas, informen AL, yang menjabat kaprodi PAI FITK UIN Raden Palembang juga menuturkan bahwa biasanya kinerja penelitian dosen, baik dalam bentuk laporan penelitian, buku, maupun artikel di jurnal, selalu relevan dengan keilmuan dosen tersebut serta program studi (Wawancara dengan informen AL, Senin 15 Agustus 2017). Dengan demikian, pada dasarnya kinerja penelitian dosen prodi PAI FITK UIN Raden Fatah Palembang selama ini selalu relevan dengan keilmuan dan institusi.

\section{Kinerja Penelitian dosen PAI berpangkat Guru Besar}

a. Hasil kerja penelitian

Untuk hasil kerja penelitian dalam bentuk kegiatan meneliti pada tiga tahun terakhir ini, informen NYK yang berpangkat Guru Besar menjelaskan bahwa ia telah melakukan penelitian kelompok pada prodi Manajemen Pendidikan Islam di tahun 2016 yang didanai oleh Lemlit UIN Raden Fatah. Selain itu, di tahun yang sama (2016), ia juga melakukan penelitian yang didanai oleh Balitbangda provinsi Sumatera Selatan tentang pencapaian Standar Penilaian pada Pendidikan Dasar dan Menengah (Wawancara dengan NYK, Senin, 14 Agustus 2017).

Informen NYK menjelaskan bahwa dalam satu tahun, kadang ia bisa melakukan tiga penelitian, baik mandiri maupun kelompok. Data ini didukung dengan hasil observasi. Tampak laporan-laporan penelitian informen NYK yang sempat peneliti observasi, misalnya berjudul Kinerja Guru PAI se-Kota Palembang Pasca Setifikasi (tahun 2015), Kinerja Mengajar Dosen Fakultas Ilmu 
Tarbiyah dan Keguruan UIN Raden Fatah Palembang (2016) (Observasi terhadap laporan-laporan kegiatan peneltian informen NYK, bulan Juli-Agustus 2017).

Dengan demikian, dapat disimpulkan bahwa informen NYK memiliki pengalaman penelitian yang cukup baik. Penelitian yang ia lakukan tidak hanya didanai oleh LP2M UIN Raden Fatah Palembang, tetapi juga dari luar UIN Raden Fatah, misalnya Balitbangda Provinsi Sumatera Selatan. Hal ini sepertinya karena dilatarbelakangi tuntutan kinerja sebagai guru besar yang harus melakukan kegiatan penelitian secara kontinyu.

Selanjutnya, informen NYK juga menjelaskan bahwa dalam tiga tahun terakhir ini ia pernah menulis buku berjudul Pola Asuh Anak dalam Tradisi Islam Melayu. Buku ini merupakan hasil penelitian yang dibukukan. Selain itu, sesuai dengan disiplin ilmunya sebagai Guru Besar, NYK menulis buku Psikologi Pendidikan pada tahun 2015. NYK juga menulis artikel di jurnal, yang paling anyar diterbitkan di jurnal Ta'dib pada tahun 2015. Sementara untuk menulis di media massa, NYK mengaku tidak pernah melakukannya karena tidak fokus.

Sesuai dengan wawancara di atas, hasil observasi menunjukkan bahwa laporan-laporan penelitian yang dihasilkan informen NYK lebih banyak ditemukan daripada buku-buku atau tulisannya dalam bentuk artikel di jurnal (Observasi hasil-hasil penelitian informen NYK, Juli-Agustus 2017). Dengan demikian, maka dapat disimpulkan bahwa pengalaman informen NYK dalam menulis buku dan menulis artikel di jurnal tidak sebanyak pengalamannya dalam melakukan kegiatan penelitian.

b. Kualitas dan Dampak kinerja penelitian

Berdasarkan hasil observasi terhadap hasil kerja penelitian informen NYK, tampak bahwa laporan-laporan penelitian yang ia lakukan sudah sesuai dengan prosedur ilmiah. Sebagian besar penelitian informen NYK menggunakan pendekatan kuantitatif. Langkah-langkah yang dilakukannya dalam penelitianpenelitian tersebut sudah memenuhi langkah-langkah keilmuan (Observasi terhadap laporan-laporan penelitian informen NYK, Agustus 2017). Sementara kalau untuk buku Psikologi Pendidikan yang merupakan karya NYK, sudah memiliki ISBN (Observasi terhadap buku Psikologi Pendidikan karya informen NYK, Agustus 2017). 
Dari sisi akademis, menurut informen NYK, dampak kinerja penelitiannya sangat banyak dirasakan ketika membimbing mahasiswa dan mengajar. Sesuai dengan penjelasan ini, salah seorang mahasiswa (BT) yang pernah menjadi bimbingan informen NYK, menjelaskan bahwa ia dibimbing NYK secara rinci.

“...dijelaske caro buat latar belakang, rumusan masalah, kerangka teori harus ado buku utama. Metodologi penelitian jugo lemak,dikasi tau tentang caro mengambil data, misal penelitian aku tentang hubungan budaya kerja dengan kinerja pegawai tata usaha. Menurut beliau, analisisnyo pake kontingensi, tapi pake data tunggal."(Wawancara dengan informen BT, mahasiswa bimbingan NYK, Selasa, 17 Oktober 2017)

Penjelasan di atas menunjukkan bahwa informen NYK menerapkan ilmu dan pengalamannya dalam meneliti ketika mengajar dan membimbing skripsi mahasiswa. Beliau membimbing mahasiswa secara rinci dan sistematis dengan metodologi penelitian yang benar. Ketika mengharuskan mahasiswa untuk mencari buku utama (buku baboon) dalam menyusun sebuah kerangka teori, hal ini mengindikasikan bahwa informen NYK ingin mengajarkan kepada mahasiswa agar terbiasa menggunakan sumber-sumber atau referensi yang primer. Selain itu, buku yang ia tulis (Psikologi Pendidikan ) menjadi salah satu buku penting yang dirujuk mahasiswa dalam perkuliahan Psikologi Pendidikan. Buku tersebut, dalam observasi peneliti, tidak hanya dikutip mahasiswa dalam penulisan makalah, tetapi juga dalam penulisan skripsi. Bahkan teman sejawat pun (sesama dosen) ada yang menggunakan buku tersebut sebagai salah satu referensi ketika menulis artikel yang relevan dengan psikologi pendidikan (Observasi makalah, skripsi mahasiswa dan tulisan dosen yang menjadikan karya NYK menjadi salah satu referensi, Agustus-September 2017). Dengan demikian, dapat dikatakan bahwa kinerja penelitian informen NYK sebagai dosen PAI yang berpangkat Guru Besar, baik dalam bentuk buku maupun laporan penelitian, memang dirasakan dampak akademisnya oleh mahasiswa dan juga rekan dosen. Sementara untuk dampak non akademis, seperti karir, NYK juga menjelaskan bahwa kinerja penelitian bermanfaat baginya untuk naik pangkat dan Laporan Beban Kinerja Dosen (LBKD).

c. Kesuksesan/kemampuan mencapai target tertentu dalam penelitian

Informen NYK menjelaskan bahwa setiap tahun ia pasti merencanakan penelitian, bahkan kadang lebih dari satu rencana penelitian. Untuk merealisasikan rencana-rencana penelitian tersebut NYK menjelaskan bahwa ia 
biasa membuat prioritas kerja. Jika rencana penelitian tersebut tidak tercapai atau tidak lulus seleksi pendanaan, maka ia akan tetap melakukan rencana penelitian itu dengan dana yang ada (Wawancara dengan informen NYK, Senin, 14 Agustus 2017). Dengan demikian, informen NYK memiliki strategi tersendiri untuk merencanakan kinerja penelitiannya, sekaligus strategi untuk mengantisipasinya.

d. Relevansi penelitian dengan unit kerja (program studi, perguruan tinggi, dan karir); dan ketepatan waktu.

Menurut informen NYK, penelitian yang ia lakukan selama ini selalu relevan dengan unit kerja, dalam hal ini relevan dengan program studi, karir dan keilmuannya. Hal ini sesuai dengan temuan peneliti terhadap hasil-hasil penelitian informen NYK. Buku Psikologi Pendidikan yang ditulis oleh informen NYK, misalnya, memang relevan dengan keilmuannya yang telah dikukuhkan sebagai Guru Besar di bidang Psikologi Pendidikan. Demikian juga dengan tema-tema penelitian yang informen NYK lakukan, selalu relevan dengan Fakultas Ilmu Tarbiyah dan Keguruan yang menjadi home base-nya.

\section{KESIMPULAN}

Dilihat dari keseluruhan data yang diperoleh melalui wawancara, observasi, dan studi dokumentasi, maka dapat dianalisis bahwa kinerja penelitian dosen prodi PAI yang diamati pada tujuh orang informen penelitian cukup beragam. Pada umumnya, baik dosen yang pengkat Lektor, Lektor Kepala, maupun Guru Besar memiliki kinerja penelitian yang meliputi kegiatan penelitian, menulis buku, dan menulis artikel di jurnal imiah. Namun, belum ada satu pun yang menulis artikel di media massa.

Jika dilihat dari aspek komposisi kinerja penelitian tersebut, maka tidak semua dosen prodi PAI FITK UIN Raden Fatah tersebut yang memiliki kinerja yang seimbang dalam melakukan penelitian, menulis buku, serta menulis artikel di jurnal ilmiah. Sebab, setiap dosen tampaknya memiliki kecenderungan masingmasing. Ada yang lebih suka melakukan penelitian, baik mandiri atau kelompok, tetapi ada pula yang lebih suka menulis buku atau artikel di media massa. Secara khusus, dosen-dosen yang berpangkat Lektor Kepala dan Guru Besar memiliki kuantitas dan kualitas kinerja yang lebih baik daripada dosen dengan pangkat Lektor. 


\section{DAFTAR PUSTAKA}

Ainsworth, Murray, dan Neville Smith. 1993. Making It Happen, Managing Performance At Work. Prentice Hall Englewoods Cliffs: New Jersey.

Arikunto, Suharsimi. 2006. Prosedur Penelitian Suatu Pendekatan Praktik.Penerbit PT. Rineka Cipta. Jakarta.

Bangun, Wilson. Manajemen Sumber Daya Manusia. 2012. Jakarta: Erlangga. Bernardin, John H. dan Joyce EA Russel. 1998. Human Resources Management, An Experiential Approach. Second Edition. McGraw Hill Book Co: New York.

Bungin, Burhan. 2003. Analisis Data Penelitian Kualitatif: Pemahaman Filosofis dan Metodologis ke Arah Penguasaan Model Aplikasi. Jakarta: Raja Grafindo Persada.

Byars, Lloyd, dan Leslie W. Rue.1979. Personnel Management : Concepts and Applications. WB Saunders Co: Philadelphia.

Cascio, Wayne F. 1989. Managing Human Resources, Productivity, Quality of Work Life, Profits. Second Edition, ( McGraw Hill Book Co: New York USA, 1989).

Crow, Lester D. dan Alice Crow. 1984. Educational Psychology, terjemahan Z. Kasijan. Surabaya: Bina Ilmu.

Ditjendikti Depdiknas. 2009. Pedoman Operasional Penilaian Angka Kredit Jabatan Fungsional Dosen Ke Lektor Kepala dan Guru Besar.

Dokumentasi Program Studi Pendidikan Agama Islam (PAI) tahun 2017

Heneman III, Herbert G dan Timothy A. Judge. 2009. Staffing Organizations. Mcgraw-Hill Education (Asia). Internantional Edition. New York.

Ivancevich, John M Robert Konopaske, Michael T. Matteson. 2008.

Organizational Behavior and Management. Mcgraw-Hill.Irwin: New York.

Mangkunegara, Anwar Prabu. 2005. Manajemen Sumber Daya Manusia Perusahaan. Bandung: Remaja Rosdakarya.

Miles, Matthew B. and A. Michael Huberman. 1992. Analisis Data Kualitatif, penerjemah Tjetjep Rohendi Rohidi. Jakarta: UI Press.

Milkovich. George T. John W. Boudreau. 1997. Human Resources Management. Richard D Irwin. A Time Mirror Higher Education . Group Inc. Co: USA. 
Newstrom, John W dan Keith Davis. 1997. Organizational Behavior, Human Behavior At Work. McGraw Hill Co. Inc: New York.

Patton, Michael Quinn. 2002. Qualitative Research \& Evaluation Methods, Thousand Oaks: Sage Publication.

Saodi, Ondi dan Aris Suherman. 2010. Etika Profesi Keguruan, (Bandung: Refika Aditama.

Scholae.co/web/read/570/penelitian dosen. antara peluang dan tantangan, diakses Rabu. 1 Maret 2017.

Singarimbun. 1987. Teknik Wawancara, Metodologi Penelitian dan Survei, Masri Singarimbun dan Sofyan Effendi, (ed). Jakarta: LP3ES.

Solihin, Ismail. 2009. Pengantar Manajemen. Jakarta: Erlangga.

Sugiyono. 2013. Metodologi Penelitian Kuantitatif, Kualitatif dan R\& D. Bandung: Alfabeta.

Sutrisno, Edy. 2010. Budaya Organisasi. Jakarta: Kencana.

Tim Prima Pena. Kamus Besar Bahasa Indonesia, Gitamedia Press.

Undang-Undang Republik Indonesia Nomor 14 Tahun 2005 Tentang Guru dan Dosen, Jakarta: CV Eko Jaya

Uno, Hamzah B dan Nina Lamatenggo. 2014. Teori Kinerja dan Pengukurannya. Bumi Aksara, Jakarta.

Wahab, Solichin Abdul. Pengantar Analisis Kebijaksanaan Negara. ( Jakarta: Rineka Cipta, 1990)

Wibowo. 2012. Manajemen Kinerja. Jakarta: Rajawali Pers.

http://www.pengertianahli.com/2013/12/pengertian-penelitian-apa-itu-

penelitian.html, diakses Senin, 27 Februari 2017.

http://kbbi.web.id/kinerja, diakses Selasa, 28 Februari 2017 